\title{
Firm attributes and human resource disclosure by listed Sri Lankan Commercial Banks
}

\author{
Kugavarathasarma. S and Ajanthan.A \\ Department of Accounting, University of Jaffna
}

\begin{abstract}
The study aimed to reveal the impact of firm attributes on human resource disclosure of listed commercial banks in Sri Lanka. Human resource disclosure is used as the dependent variable for the study whilst the independent variables constituted some attributes of firm that can impact on the bank's human resource disclosure such as size, age, profitability and leverage. This research applied quantitative approach by testing variables through descriptive analysis, multi correlation and regression analysis. Data is collected from 65 annual reports which are related to 13 commercial banks listed in Colombo Stock Exchange for five years from 2013 to 2017. Content analysis also was applied to analyze the extent of human capital disclosure. This study revealed that only the firm size showed significant positive impact to the disclosure of human capital, while age, profitability and leverage did not bring significant effect. In addition, based on the results of content analysis it can be concluded that human resource policy related disclosure is quite highly disclosed (approximately 85\%) by Sri Lankan banks by using words as way of disclosure.
\end{abstract}

Keywords: Colombo Stock Exchange, Commercial Banks, Content Analysis Firm Attributes, Human Resource Disclosure 


\section{Introduction}

The success of any organization depends on the quality and efficiency of its human resources (HR) apart from other critical parameters. According to Schultz (1961) HR can be defined as abilities and skills of certain group of people or an individual person that have value which includes behavior, experience, knowledge, morale and attitude and altogether give economic value to the organization. In this connection, Conventional Firm Theory posits that firms maximise their value by making decisions to maximise the shareholders' wealth (Graham, Harvey, \& Puri, 2015). Intellectual capital (IC) disclosure, a key input to achieving that goal, it has been receiving an increasing amount of attention among the firms around the world. This is due to the new economy driven which is knowledge-based economy where value creation become one of the crucial issues in the world and tends to be based on intangible rather than financial and physical assets. The accounting literature identifies these intangible value drivers as IC. IC 'is the possession of knowledge and experience, professional knowledge and skills, good relationships, and technological capacities, which when applied will give organisations competitive advantage' (CIMA, 2001). Human Capital (HC) is an important element of IC (Guthrie \& Petty, 2000 and Sveiby, 1997), driving value creation in the new economy and especially in knowledge intensive or service companies.

In recent years, there has been increasing dissatisfaction with traditional financial reporting and its ability to provide stakeholders with sufficient information on a company's ability to create wealth (Boesso \&
Kumar, 2007; Bozzolan, Favotto, \& Ricceri, 2003;Francis \& Schipper, 1999 and Lev \& Zarowin, 1999). As consequence, raising the need for a different type of information such as disclosure of IC information which brings considerable value to a firm (Abeysekera \& Guthrie, 2005 and Guthrie, Petty, \& Ricceri, 2006) because of the main objective of IC disclosure is to satisfy the information needs of users in a manner that enables both decision making and accountability (Firer \& Williams, 2003 and Guthrie \& Petty, 2000) and finally inform the stakeholders about the quality and value of the firm (Spence, 1973). In addition, Boesso and Kumar (2007) state that voluntary disclosure is aimed at providing a clear picture to stakeholders about the long-term survival of the firms by reducing information asymmetry and agency conflicts between principal and agent. Agency theory would suggest disclosure as a way to reduce agency costs due to, among other things, information asymmetry (Macagnan, 2009 and Wagenhofer, 1990). On the other hand, the proprietary costs theory indicates that disclosure might increase the company's costs (Wagenhofer, 1990). Consequently, according to these theories, the likelihood that managers voluntarily disclose information depends on certain factors that are characteristic of the company (Macagnan, 2009 and Williams, 2001) such as size, debt, profitability, degree of monopoly and marketto-book ratio that may motivate managers to voluntarily disclose or withhold information. In other words, managers' decisions to voluntarily reveal or conceal information may be related to the economic characteristics of the company. 
Understandably, the disclosure of information regarding intangible assets, specifically $\mathrm{HC}$, has strategic relevance for enterprises because these features, although not always recorded in accounting, represent a competitive business edge in the current economy. Tangible and financial assets are more easily purchased in the market than is a qualified group of professionals. Professionals' qualifications involve costs due to training and time, thus creating opportunities for innovation that will boost a company's competitiveness. Therefore, the competitive edge of a company may be found in the creation and maintenance of its intangible assets. In other words, the increased relevance given to information regarding intangible assets is due to the benefits afforded by such information, such as 'increased productivity, increased profit margins, and, most importantly, innovative products and processes, which are the only means companies can use to escape intense competitive pressure' (Lev, 2004). Therefore, the disclosure of HC information may provide benefits to a company, such as those resulting from the reduction of information asymmetry; however, it may also trigger a reaction from competitors, which can result in a loss of competitive advantage.

HC disclosure has received considerable academic and practitioner attention across the globe during the past decade. So that, many researchers have investigated determinants of overall and specific voluntary disclosures. But, very few studies have attempted to study determinants of HR disclosures of companies (Abeyasekara \& Guthrie, 2004; Alam \& Deb, 2010; América
Álvarez Domínguez, 2012; Brown, Tower, \& Taplin, 2005;Fontana \& Macagnan, 2013 and Jindal \& Kumar, 2012). The firms in the developed countries are usually disclose HR information in formal pattern in their annual reports but in the developing countries like Sri Lanka, HR disclosure aspect is very new concept and it is still in infant stage. Though it is not compulsory for the companies in Sri Lanka, but they are making some HR disclosure voluntarily (Abeyasekara \& Guthrie, 2004). There has been a scarcity of research on HR disclosure in the perspective of emerging economies (Abeyasekara \& Guthrie, 2004 and Khan \& Khan, 2010). As the human resource has been considered as tactical capital, its accounting and disclosure aspects are becoming significant for the organizational success. So far our knowledge concern, no rigorous research studies have been done on human resource disclosure in annual report of commercial banks in Sri Lanka. Hence, this study aims at examining the extent of HR disclosures and identifying their determinants for listed commercial banks.

This paper is organised as follows: Section 1.2 shows the research questions; Section 1.3 objectives of the study; Section 1.4 literature review and hypotheses development; Section 1.5 represents the research methods; Section 1.6 shows the results \& discusiion and Section 1.7 ends with the conclusion of the study.

\section{Research questions}

The research question is what the researcher is expected to answer, and how it will work and the academic body of knowledge for this study, 
the researcher aimed to provide possible answer to following questions:

RQ1: What is the impact of firm attributes on HR disclosure?

RQ2: What is the relationship between firm attributes and HR disclosure?

\section{Objectives of the study}

The main objective of the study is "to identify the impact of firm attributes on HR disclosure of listed commercial banks in Sri Lanka."

Secondary objective is:

- To examine the relationship between the firm attributes and HR disclosure of listed commercial banks.

\section{Literature review and hypotheses development}

Theoretical review

The three theories used in this study are Agency Theory, Signaling Theory and Stakeholder Theory. It is suggested by Beattie (2014) that studies within accounting narrative would benefit from wider use theories. These three theories are most commonly reviewed in the area of voluntary disclosure and are suggested as a framework by (An, Davey, \& Eggleton, 2011). Solely the presented theories do not serve as a sufficient theoretical framework; therefore all three have been used, as the theories are linked (An et al., 2011).

\section{Agency Theory}

Agency Theory deals with the cost incurred when delegating responsibility inside an organization. Jenses \& Meckling (1976) define the agency relationship as dealing where the principal delegates responsibility to the agent. A common case is when the shareholder is the principal and the manager is the agent. The managers' decisions might differ from the shareholders, so that the decisions made by the manager might not always be the most preferred, when see from a shareholders' perspective. Consequently it becomes as a problem for the principal to delegate responsibility to the agent. This is what Jensen and Meckling (1976) told as agency cost. An important view of Agency Theory is the information asymmetry, which is when one party has access to more information than the other. The agency costs will increase with information asymmetry which may lead to two types of agency problems. One called as moral hazard or hidden costs where the manager might work to slow or give himself too many benefits. The principal has limited access to observe the performance of the manager and can only assess it based on the outcome. The second agency problem is adverse selection. The manager provides the information and can therefore choose what to disclose to his own benefit (Subramaniam,2006).

\section{Signaling Theory}

This theory also deals with information asymmetry. The party access more information can signal in order to reduce it. The signal can implies quality and enhance positive characteristics of the signaler. Morris (1987) explains the theory by the example of a buyer and a seller. He says that, "sellers in a market are assumed to keep more information about their product then buyers. If buyers possess no information about specific products but do have some general perceptions, the buyers will value all products at the same price which is a weighted average of their general perceptions". This implies that even sellers have good quality products suffer opportunity loss since their products could sell at a higher price if 
customers knew about the higher quality. While sellers of below average products, make an opportunity gain. In order for the high quality seller to stay in the market he must communicate his superior quality to the buyers. Morris (1987) more explains that this communication is done through signals (for example after sale services), which indicates the superior quality. In order for this to work the signaling cannot be easily copied by the poor quality sellers, therefore the signaling cost have to be inversely related to quality.

\section{Stakeholder Theory}

Now looking on the theory that takes a diversify perspective, the Stakeholder Theory. A stakeholder is defined by Freeman (2010) as "any group or individual who can affect or is affected by the achievement of the organization's' purpose”. According to Deegan \& Unerman (2011), Stakeholder Theory has both an ethical branch and a managerial branch. Generally the banking sector is subject to a more diverse and complex publics than most other sectors of the economy (Upadhyay \& Dhungel, 2012) due to the nature of its business and its importance to every sector of the economy. Besides, employees are direct contributors to the generation of profit thus they are classified as primary stakeholder group as they are able to exercise strong power on the firm (Boolaky, 2011 and Cuganesan, 2007). Besides, there is growing evidence of the interest and demand among other stakeholders for information from the firm in relation to $\mathrm{HC}$ (Micah, Ofurum, \& Ihendinihu, 2012). Therefore according to Cuganesan, Carlin, \& Finch (2009) measuring and reporting HC can be an important means of ensuring that all stakeholders are fully informed of the value creation potential of the business. The more disclosures are made; the more informed will be the stakeholders. According to Samudhram, Sivalingam and Shanmugam (2010), nondisclosure of HC based information contributes to the information asymmetry problem. Annual reports are prepared disclosing information relating to the various key aspects of an organization in order to deal with information asymmetry problem as stated in the above section. The most essential role of annual reports is to provide relevant, useful and reliable economic information to investors, shareholders and other interested people (Binh, 2012). So the information disclosed in the annual report, is geared primarily to these external users (Flamholtz, 2001). This is the reason stakeholder theory is considered to providing insight on disclosures relating to $\mathrm{HR}$ hence is adopted by the current study.

\section{Empirical studies}

\section{Firm Size}

Size can be measured by several indicators such as turnover, sales, revenues, total assets and number of employees. When looking at company size and voluntary disclosure there are two obvious reasons that larger companies should disclose more information. Firstly, they have the resources to disclose more information. Secondly, large firms have better internal management information systems and therefore they are able to disclose more information (Ousama, Fatima, \& Hafiz-Majdi, 2012). From a stakeholder perspective, larger firms are more likely to be of interest to the general public. They usually have more shareholders interested in voluntary disclosure 
and are more likely to use formal channels to share the information (Roberts, 1992). According to Jensen and Meckling (1976) the idea that larger companies have greater social reputation and the agency and political cost are higher is the reason for considering this variable in most research on voluntary and mandatory disclosure. There are several reasons in the literature in an attempt to support this positive association. Firstly, the cost of accumulating and generating certain information is greater for small firms than large firms. Small companies may not be able to afford such costs from their resource base. Larger companies might have sufficient resources to afford the cost of producing information for the user of annual report. Secondly, the agency cost is higher for large firms because shareholders are widespread and in that way, disclosing more information reduce the potential agency cost (Watts \& Zimmerman, 1983). Additionally, these firms might publish more information in their reports to supply information relevant to different users. Thirdly, larger companies may tend to disclose more information than smaller companies in their annual reports due to their competitive cost advantage (Lobo \& Zhou, 2001). Hence, small companies disclose less information than large companies. Brammer and Pavelin (2006) argue that large companies are more visible and therefore under greater pressure from their stakeholders. Large companies also have lower costs of gathering and publishing relevant information (América Álvarez Domínguez, 2012). Due to this, and many other reasons, one can presume that large companies disclose more information than smaller ones. There are many previous studies that have found mixed association between company size and voluntary disclosure (Bharathi Kamath, 2008; Broberg, Tagesson, \& Collin, 2010;Guthrie, Petty, \& Ricceri, 2006; Maheshwari, 1993; Mamun, 2009; Watson, Shrives, \& Marston, 2002 and White, Lee, \& Tower, 2007). There is a question whether firm size would lead to more voluntary disclosue of HC. This above reasoning led to the following hypothesis:

$H_{1}$ :There is a significant impact of firm size on HR disclosure.

\section{Firm Age}

Age as a determinant for disclosure could be explained by Stakeholder Theory. Organizations that have been listed for a longer time have a longer history and a reputation of providing stakeholders proof of their social responsibility. The stakeholders expect the company to continue to provide voluntary disclosure and may react to any drastic changes in strategies (Roberts, 1992). It can also be explained by Legitimacy Theory. In order to be perceived as legitimate the organizations need to inform society of their legitimacy. An organization that has been listed for a longer time must have incorporated the resource of legitimacy in its culture in order to survive (Deegan, 2006). Hossain \& Hammami (2009); Prencipe (2004) and White et al.(2007) point out that older companies disclose more information. At the same time, Rimmel, Nielsen and Yosano (2009) note that younger companies disclose more IC information in the annual reports. There are many previous studies (Hossain and Hammami, 2009; Alam and Deb, 2010 and Jindal and Kumar, 2012) 
show inconclusive result on the relationship between age and HR disclosure. There is a question whether firm age would lead to more voluntary disclosue of HC. This above reasoning led to the following hypothesis:

$\mathrm{H}_{2}$ :There is a significant impact of firm age on HR disclosure

\section{Profitability}

Signaling Theory suggests that companies should signal their advantages to the market (Whiting \& Miller, 2008). Profitability is of many considered to be an indicator of investment quality (Prencipe, 2004). Therefore Signaling Theory can be applied to suggest a positive relationship between profitability and voluntary disclosure (Ousama et al., 2012). Companies which are highly profitable will increase the extent of their disclosure, in general, to reduce agency costs, to avoid giving out bad signs to the market and to justify earnings to avoid political costs (Giner, 1997). High tech companies generally have a larger gap between book value and market value and therefore these companies depend on voluntary disclosure to a larger extent (Guo, Lev, \& Zhou, 2005). It is more likely for highly profitable companies to disclose good news to decrease the risk of getting undervalued (Oliveira, Rodrigues \& Craig, 2006). In 2012, Singhvi argues that when profitability is high and the company achieves a high margin of profit, the managerial groups are motivated to disclose more information in order to show off good reputation to the consumers, shareholders, investors and other stakeholders. The empirical evidences from previous studies are inconclusive. Ousama et al. (2012), Guo, Lev, \& Zhou (2005); Haniffa and Cooke (2002) and
Broberg, Tagesson \& Collin (2010) note a positive relationship between profitability and voluntary disclosure. However Hossain and Hammami (2009), Oliveira et al. (2006) and Prencipe (2004) did not find a significant relationship. There is a question whether profitability would lead to more voluntary disclosue of HC. This above reasoning led to the following hypothesis:

$H_{3}$ :There is a significant impact of profitability on HR disclosure

\section{Leverage}

Because of the separation of ownership and control, agency costs arise (Jensen \& Meckling, 1976). Looking at both Agency Theory and Signaling Theory, disclosure of information is a way for management to signal that they act in the best interest of the owners (Singh \& Van der Zahn, 2008). In accordance with Agency Theory, if a larger amount of capital is delegated to the agents, the agency costs must also be higher. Companies with a larger market capitalization should therefore have higher agency costs (Jensen \& Meckling, 1976). Companies can reduce agency costs through more disclosure and it would therefore be a larger incentive for them to provide more voluntary disclosure (An et al., 2011).In a company where the ownership is more concentrated the owners are more likely to have access to information and not be as dependent on the annual report ( $\mathrm{Li}$, Pike, \& Hanifa, 2008). Companies with more dispersed ownership are expected to disclose more information (Prencipe, 2004). Haniffa and Cooke (2002), Oliveira et al. (2006) and Prencipe (2004) found that companies with more dispersed shares disclosed more 
information. White et al. (2007), Whiting and Woodcock (2011) and Ferreira, Branco and Moreiran (2012) did not find any significant relevance. Even though the empirical evidence is mixed, companies with less ownership concentration is predicted to disclose more, in line with Prencipe (2004).Agency Theory can also be used to predict the level of voluntary disclosure in relation to the level of leverage in a company (Whiting \& Woodcock, 2011). If a firm gets debt from the outside, agency cost will arise due to the different interests of the debt holders and equity holders (Berger \& Patti, 2006). These agency costs can be reduced by disclosure of information and thus gives an incentive for firms with more debt to disclose more (Oliveira et al., 2006). In contrast, firms with low level of leverage also have an incentive to disclose more to show their advantage, which are in accordance with Signalling Theory (Oliveira et al., 2006). Previous studies show mixed outcomes on the relationship between leverage and HR disclosure. Broberg et al. (2010), Prencipe (2004), White et al. (2007) and Williams (2001) found that firms with more debt had more voluntary disclosure. On the other hand, Whiting and Woodcock (2011), Haniffa and Cooke (2002) and Oliveira et al. (2006), among others, found no significant relationship between the level of leverage and voluntary disclosure. There is a question whether profitability would lead to more voluntary disclosue of HC. This above reasoning led to the following hypothesis:

$\mathrm{H}_{4}$ :There is a significant impact of leverage on HR disclosure

\section{Research methods}

All listed commercial banks are selected as the sample of the study. There are 13 listed commercial banks in this sector. Justification for selecting the listed commercial banks as the sample for this study is, Wickramasinghe and Fonseka (2012) note that HR as more important factor especially to the service-based sector than any other sector of a country. The reason being application of strategy in service business is mainly dependent on $\mathrm{HC}$ and employees (Cuganesan, 2006). Within the service-based sector, according to Handley, Juleff and Paton (2007) financial service sector is a key part, and banks are the most significant component therein. And also Handley et al., (2007) add that the banks offer all important services of giving deposit and loan facilities for personal and corporate customers, making credit and liquidity available in adverse market conditions, and providing access to the nation's payments systems. The banks serve every other sector in the economy. As a result, the banking sector is described as a key contributor to stability and growth of the economy as a whole and of other business enterprises and is highly visible to public scrutiny (Goh, 2005; Mondal \& Ghosh, 2012 and Olagunju, Olurin, \& Okuyemi, 2012). The sources of the data were from 2013 to 2017 financial reports. In determining the level of intellectual capital disclosure provided by firm, content analysis was performed on annual reports.

HR disclosure indicators

To measure HC disclosure, the study employed content analysis, a method that has been applied by prior literature in measuring IC disclosure (Beattie \& Thomson, 2007; Li , Mangena, \& Pike, 2012; Li et al, 2008). The 
study applied framework tested by Ullah, Uddin and Khanam (2015) which provides comprehensive list of valuntary HR items divided into seven cateories such as HR policies, Financial information on HR, Basic

Table 1. HR disclosure indicators

\begin{tabular}{|c|c|c|}
\hline HR Policies & Basic HR Information & HR Development \\
\hline 1. Policy of Compensation & $\begin{array}{l}\text { 1.Statutory(avg) Number of } \\
\text { Employee by Category }\end{array}$ & Employee Career Development \\
\hline 2. Policy of Reward & 2.Vocational Qualification & 2. Employee Productivity \\
\hline 3.Policy of Communication & 3.Work-related Knowledge & 3. Training Program \\
\hline 4. Policy of Training & 4.Work-related Competencies & 4. Employee motivation \\
\hline 5. Policy of Safety & 5.Employee Age & 5. Nature of Training \\
\hline $\begin{array}{l}\text { 6.Policy towards Equal } \\
\text { Opportunities }\end{array}$ & 6.Employee Diversity & $\begin{array}{l}\text { 6.Categories of Employee } \\
\text { Trained }\end{array}$ \\
\hline $\begin{array}{l}\text { 7.Policy towards } \quad \text { Racial } \\
\text { Equality }\end{array}$ & 7. Employee Capabilities & 7. Number of Employee Trained \\
\hline $\begin{array}{l}\text { 8.Policy towards Sexual } \\
\text { Equality }\end{array}$ & $\begin{array}{l}\text { 8. Geographical Distribution of } \\
\text { Employees }\end{array}$ & $\begin{array}{l}\text { 8.Future Plan of HR } \\
\text { Development }\end{array}$ \\
\hline $\begin{array}{l}\text { 9.Policy related to HR } \\
\text { Development }\end{array}$ & 9. Categories of Employee by Sex & HR Other Factors \\
\hline Financial Information on HR & 10. Employee Service by Years & 1.Entrepreneurial Spirit of HR \\
\hline 1.Statutory Wages & 11. Employment Report & 2.Separate HRA Statement \\
\hline 2. Provident Fund & 12. Special Know how/Skills & 3. Management Succession Plan \\
\hline $\begin{array}{l}\text { 3.Employee/Executive } \\
\text { Compensation }\end{array}$ & HR Relationship \& Culture & 4. Welfare Information \\
\hline 4. Managerial Remuneration & 1.Union Activity & Health \& Safety \\
\hline 5. Retirement Benefits & 2.Employee Attitude/Behaviour & 1.Health\& Safety at Work \\
\hline 6. Revenue Per employee & 3. Employee Commitments & 2. Toxic Hazards \\
\hline 7. Cost of Safety Measure & $\begin{array}{l}\text { 4.Employee-Employee } \\
\text { Relationship }\end{array}$ & $\begin{array}{l}\text { 3.Any Reference to Health\& } \\
\text { Safety Law/ Inspection }\end{array}$ \\
\hline 8.Awards\& Rewards & $\begin{array}{l}\text { 5.Employee-Management } \\
\text { Relationship }\end{array}$ & $\begin{array}{l}\text { 4.Information to Employees, } \\
\text { Training Health \&Safety issues }\end{array}$ \\
\hline 9. Loans\& Advance to HR & 6. Job Environment & $\frac{\text { HR Importance to }}{\text { Organization }}$ \\
\hline $\begin{array}{lll}\text { 10.Amount } & \text { Spent } & \text { on } \\
\text { Recruitment } & & \\
\end{array}$ & 7. Employee Teamwork & 1.Performance Recognition \\
\hline 11.Amount Spent on Training & $\begin{array}{l}\text { 8.Cultural Function/ } \\
\text { Entertainment }\end{array}$ & $\begin{array}{l}\text { 2.Employee Participation in } \\
\text { Decision Making }\end{array}$ \\
\hline 12. HR development Fund & 9. Annual Picnic/ Travelling & $\begin{array}{l}\text { 3. Recognizing HR Importance } \\
\text { to Organization }\end{array}$ \\
\hline 13. Employees' fund & 10. Sports Activities & \\
\hline $\begin{array}{l}\text { 14.Provision for Employee } \\
\text { Benefits }\end{array}$ & 11. Punishment to HR & \\
\hline 15. Employee Life Insurance & 12. Employee Turnover & \\
\hline $\begin{array}{l}\text { 16.Employee } \\
\text { Facilities }\end{array}$ & & \\
\hline
\end{tabular}

Source: Ullah, Uddin and Khanam (2015)

Content analysis is used to identify the HR Undisclosure index has been calculated for each of weighted Disclosure Index (HRDI) and the
HR information, HR relationship \& culture, HR other factors and Healthy and safety. importance to firms, HR development, HR 
study. HRDI was developed based on a dichotomous procedure in which an item scores ' 1 ', if disclosed and ' 0 ', if do not disclosed a content of 68 items. Then total disclosed (HRDI) score for a listed commercial bank was calculated as additive as follows:

$$
\text { HRDI }=\sum_{i=1}^{n} d i
$$

Where, $\mathrm{d}=1$ if the item $d i$ is disclosed ; 0 if the item $d i$ is not disclosed; $\mathrm{n}=$ number of items

\section{Results and discussion}

Data Presentation

Table 2 illustrates the number of HR indicator disclosed out of the 71 indicators which are used in this study, as well as explain the percentage of that disclosure. And also researcher ranks the listed commercial banks according to their last five years disclosure level in each annual report.

Table 2. Number of HR disclosure, Percentage of HR disclosure, Rank of Listed Commercial Banks

\begin{tabular}{l|cccccc|cccc|ccc|ccc|}
\hline \multirow{2}{*}{ Banks } & \multicolumn{3}{|c|}{2013} & \multicolumn{4}{c|}{2014} & \multicolumn{3}{c|}{2015} & \multicolumn{3}{c|}{2016} & \multicolumn{3}{c|}{2017} \\
\cline { 2 - 14 } & No & $\%$ & $\mathrm{R}$ & No & $\%$ & $\mathrm{R}$ & No & $\%$ & $\mathrm{R}$ & No & $\%$ & $\mathrm{R}$ & No & $\%$ & $\mathrm{R}$ \\
\hline AMB & 30 & 42 & 10 & 28 & 39 & 12 & 35 & 49 & 11 & 35 & 49 & 10 & 39 & 55 & 11 \\
COB & 57 & 80 & 1 & 56 & 79 & 1 & 60 & 85 & 1 & 55 & 77 & 2 & 53 & 75 & 3 \\
DFCC & 44 & 62 & 6 & 49 & 69 & 5 & 49 & 69 & 6 & 51 & 72 & 4 & 57 & 80 & 2 \\
HNB & 50 & 70 & 4 & 52 & 73 & 2 & 53 & 75 & 3 & 46 & 65 & 8 & 45 & 63 & 8 \\
MBSL & 49 & 69 & 5 & 46 & 64 & 6 & 38 & 54 & 9 & 47 & 66 & 7 & 44 & 62 & 9 \\
NDB & 39 & 54 & 7 & 42 & 59 & 8 & 49 & 69 & 6 & 46 & 65 & 8 & 49 & 69 & 7 \\
NTB & 30 & 42 & 10 & 45 & 63 & 7 & 52 & 73 & 4 & 50 & 70 & 5 & 49 & 69 & 7 \\
PAB & 28 & 39 & 12 & 27 & 38 & 13 & 30 & 42 & 13 & 29 & 41 & 13 & 34 & 48 & 12 \\
SAB & 53 & 75 & 3 & 52 & 73 & 2 & 52 & 73 & 4 & 53 & 80 & 3 & 50 & 70 & 5 \\
SDB & 22 & 31 & 13 & 32 & 45 & 11 & 32 & 45 & 12 & 29 & 41 & 13 & 40 & 56 & 10 \\
SEB & 55 & 77 & 2 & 52 & 73 & 2 & 54 & 76 & 2 & 57 & 69 & 1 & 58 & 81 & 1 \\
HDFC & 37 & 52 & 8 & 41 & 57 & 9 & 37 & 52 & 10 & 29 & 41 & 13 & 30 & 42 & 13 \\
UBC & 31 & 43 & 9 & 34 & 47 & 10 & 46 & 65 & 8 & 49 & 69 & 6 & 52 & 73 & 4 \\
\hline
\end{tabular}

Source: Developed by the Researcher

Table 3 explains the ways are used to disclose the HR indicators in the annual reports and also indicates the number of words, number of graphs, number of charts and number of pictures are used by listed commercial banks in their last five year annual reports.

Table 3. Number of words, number of graphs, number of charts and number of picture used for HR disclosure

\begin{tabular}{|c|c|c|c|c|c|c|c|c|c|c|c|c|c|c|c|c|c|c|c|c|}
\hline \multirow{3}{*}{$\begin{array}{r}\text { Bal } \\
\mathrm{s} \\
\end{array}$} & \multicolumn{5}{|c|}{ Words } & \multicolumn{5}{|c|}{ Graphs } & \multicolumn{5}{|c|}{ Charts } & \multicolumn{5}{|c|}{ Pictures } \\
\hline & 13 & 14 & 15 & 16 & 17 & 1 & 1 & 1 & 1 & 1 & 1 & 1 & 1 & 1 & 1 & 1 & 1 & 1 & 1 & 1 \\
\hline & 141 & 135 & 183 & 184 & 135 & & 4 & 5 & 6 & & 3 & 4 & 5 & 6 & 7 & 3 & 4 & 5 & 6 & 7 \\
\hline AMI & $\begin{array}{c}141 \\
5\end{array}$ & $\begin{array}{c}135 \\
9\end{array}$ & $\begin{array}{c}183 \\
8\end{array}$ & $\begin{array}{c}184 \\
5\end{array}$ & $\begin{array}{c}135 \\
6\end{array}$ & 3 & 2 & 2 & 2 & 2 & 4 & 3 & 3 & 2 & 4 & 0 & 1 & 1 & 2 & 4 \\
\hline $\mathrm{COB}$ & $\begin{array}{c}286 \\
5\end{array}$ & $\begin{array}{c}276 \\
9\end{array}$ & $\begin{array}{c}423 \\
5\end{array}$ & $\begin{array}{c}348 \\
7\end{array}$ & $\begin{array}{c}287 \\
9\end{array}$ & $\begin{array}{l}1 \\
1\end{array}$ & 3 & $\begin{array}{l}2 \\
0\end{array}$ & $\begin{array}{l}2 \\
2\end{array}$ & $\begin{array}{l}1 \\
9\end{array}$ & 9 & $\begin{array}{l}1 \\
0\end{array}$ & 2 & 2 & 4 & 0 & 0 & 1 & 5 & 3 \\
\hline DFC & $\begin{array}{c}232 \\
5\end{array}$ & $\begin{array}{c}210 \\
2\end{array}$ & $\begin{array}{c}312 \\
4\end{array}$ & $\begin{array}{c}310 \\
2\end{array}$ & $\begin{array}{c}312 \\
5\end{array}$ & 5 & 2 & 2 & 6 & 7 & 6 & $\begin{array}{l}1 \\
5\end{array}$ & $\begin{array}{l}1 \\
2\end{array}$ & $\begin{array}{l}1 \\
2\end{array}$ & 9 & 1 & 0 & 0 & 0 & 2 \\
\hline HNE & $\begin{array}{c}256 \\
8\end{array}$ & $\begin{array}{c}267 \\
8\end{array}$ & $\begin{array}{c}386 \\
9\end{array}$ & $\begin{array}{c}262 \\
0\end{array}$ & $\begin{array}{c}184 \\
5\end{array}$ & 4 & 0 & 7 & 8 & 8 & 9 & 8 & 4 & $\begin{array}{l}1 \\
3\end{array}$ & $\begin{array}{l}1 \\
1\end{array}$ & 5 & 4 & 5 & 4 & 3 \\
\hline MBs & $\begin{array}{c}246 \\
0\end{array}$ & $\begin{array}{c}220 \\
9\end{array}$ & $\begin{array}{c}184 \\
5\end{array}$ & $\begin{array}{c}289 \\
7\end{array}$ & $\begin{array}{c}194 \\
8\end{array}$ & 4 & 6 & 0 & 9 & $\begin{array}{l}1 \\
1\end{array}$ & 4 & 3 & 3 & 5 & 6 & 0 & 0 & 0 & 2 & 4 \\
\hline $\mathrm{NDE}$ & $\begin{array}{c}236 \\
5\end{array}$ & $\begin{array}{c}210 \\
5\end{array}$ & $\begin{array}{c}281 \\
5\end{array}$ & $\begin{array}{c}264 \\
1\end{array}$ & $\begin{array}{c}220 \\
1\end{array}$ & 4 & 4 & 5 & 4 & 1 & 3 & 2 & 3 & 3 & 4 & $\begin{array}{l}1 \\
1\end{array}$ & 6 & 9 & 7 & 6 \\
\hline NTB & $\begin{array}{c}148 \\
9\end{array}$ & $\begin{array}{c}200 \\
8\end{array}$ & $\begin{array}{c}364 \\
5\end{array}$ & $\begin{array}{c}304 \\
5\end{array}$ & $\begin{array}{c}245 \\
6\end{array}$ & 7 & $\begin{array}{l}1 \\
6\end{array}$ & $\begin{array}{l}1 \\
1\end{array}$ & 1 & 1 & 1 & $\begin{array}{l}1 \\
2\end{array}$ & 4 & 3 & 4 & 6 & $\begin{array}{l}1 \\
1\end{array}$ & 5 & 6 & $\begin{array}{l}1 \\
1\end{array}$ \\
\hline
\end{tabular}




\begin{tabular}{|c|c|c|c|c|c|c|c|c|c|c|c|c|c|c|c|c|c|c|c|c|}
\hline PAB & $\begin{array}{c}130 \\
2\end{array}$ & $\begin{array}{c}112 \\
3\end{array}$ & $\begin{array}{c}134 \\
2\end{array}$ & $\begin{array}{c}156 \\
4\end{array}$ & $\begin{array}{c}126 \\
4\end{array}$ & 2 & 1 & 1 & 4 & 1 & 0 & 1 & 1 & 1 & 2 & 3 & 2 & 3 & 4 & 5 \\
\hline $\mathrm{SAB}$ & $\begin{array}{c}275 \\
4\end{array}$ & $\begin{array}{c}273 \\
4\end{array}$ & $\begin{array}{c}321 \\
6\end{array}$ & $\begin{array}{c}346 \\
2\end{array}$ & $\begin{array}{c}241 \\
6\end{array}$ & 4 & 5 & 7 & 8 & $\begin{array}{l}1 \\
1\end{array}$ & 5 & 9 & 5 & $\begin{array}{l}1 \\
1\end{array}$ & 7 & 2 & 2 & 2 & 4 & 3 \\
\hline SDB & 985 & $\begin{array}{c}113 \\
8\end{array}$ & $\begin{array}{c}159 \\
8\end{array}$ & $\begin{array}{c}120 \\
4\end{array}$ & $\begin{array}{c}110 \\
6\end{array}$ & 3 & 2 & 3 & 4 & 2 & 0 & 4 & 3 & 3 & 3 & 3 & 2 & 3 & 4 & 5 \\
\hline SEB & $\begin{array}{c}273 \\
8\end{array}$ & $\begin{array}{c}254 \\
8\end{array}$ & $\begin{array}{c}412 \\
6\end{array}$ & $\begin{array}{c}354 \\
6\end{array}$ & $\begin{array}{c}364 \\
5\end{array}$ & 1 & 0 & 6 & 5 & 7 & 8 & $\begin{array}{l}1 \\
7\end{array}$ & $\begin{array}{l}2 \\
1\end{array}$ & $\begin{array}{l}1 \\
4\end{array}$ & 6 & 2 & 4 & 6 & 3 & 9 \\
\hline HDF & $\begin{array}{c}154 \\
6\end{array}$ & $\begin{array}{c}184 \\
0\end{array}$ & $\begin{array}{c}189 \\
6\end{array}$ & $\begin{array}{c}131 \\
5\end{array}$ & $\begin{array}{c}134 \\
5\end{array}$ & 4 & 3 & 5 & 4 & 1 & 2 & 2 & 1 & 3 & 6 & 4 & 3 & 2 & 3 & 2 \\
\hline UBC & $\begin{array}{c}144 \\
8 \\
\end{array}$ & $\begin{array}{c}134 \\
6 \\
\end{array}$ & $\begin{array}{c}218 \\
4 \\
\end{array}$ & $\begin{array}{c}300 \\
8 \\
\end{array}$ & $\begin{array}{c}314 \\
5 \\
\end{array}$ & 3 & 4 & 4 & 4 & 3 & 2 & 2 & 5 & 6 & 4 & 1 & 7 & 4 & 4 & 5 \\
\hline
\end{tabular}

Source: Developed by Researcher

Descriptive statistics

Table 4 illustrates the descriptive statistics for proxies of firm attributes such as TA, AGE, EPS, DAR and HRDI as the overall index for the HR disclosure. The data containing, 65 observations which were collected from the annual reports of the respective listed commercial banks. The HRDI varies between the banks as the maximum is 0.845 and minimum is 0.309 . Which implies that banks disclose 84.5 percentage as maximum and 30.9 percentage as minimum in their annual reports. On the average HRDI is 0.616 this means over the last five years each banks averagely disclose 61.6 percentage of HR indicators in their annual reports therefore it clearly shows that banks disclosed more than half of the information and there is a place for improvement in terms of $\mathrm{HR}$ disclosure of Table 4. Descriptive statistics for TA, AGE, EPS, listed commercial banks in Sri Lanka as disclosing the HR is at the emerging stage. The TA shows the average value of Rs. 283886.9 million with standard deviation of Rs285905.6 million and it varies significantly among the banks from Rs. 13229 million to Rs. 1143374 million. Mean value of AGE is 25.231. Which are approximately 25 years and the minimum and maximum AGE are 3 years and 61 years respectively. EPS shows an average of Rs12.65 with the standard deviation of Rs.13.153 which implies banks averagely give Rs. 12.5 per equity shares for their shareholders. The variation of earnings on the each equity share is Rs. -0.47 to Rs. 65.95 . Finally the DAR shows the average as 0.885 ( 88.5 percentage) with the standard deviation of 0.067 (6.7 percentage) and also it holds the minimum and maximum percentages of 63 and 95 respectively.

\begin{tabular}{l|rrrrr}
\hline \multicolumn{1}{c}{ Variable } & Obs & Mean & Std.Dev & Min & Max \\
\hline TA (Rs) & 65 & 283886.9 & 285905.6 & 13269 & 1143374 \\
AGE(years) & 65 & 25.231 & 15.279 & 4.000 & 61.000 \\
EPS(Rs) & 65 & 12.650 & 13.153 & -0.470 & 65.950 \\
DAR(\%) & 65 & 0.885 & 0.067 & 0.630 & 0.950 \\
HRDI(\%) & 65 & 0.616 & 0.139 & 0.309 & 0.845 \\
\hline
\end{tabular}

\section{Source: Results from the panel data analysis}

Table 5 illustrates the descriptive statics for category-wise HR disclosure in the annual reports. In total nine HR Policy indicators are considered in this study. On an average banks disclosed 84.4 percentage in their annual reports and the disclosure level of this information varies between 33.3 percentages to 100 percentage. It clearly shows that some banks disclose all 9 HR Policy information in their annual reports. This study considers 12 
Basic HR Information to be disclosed in the annual reports. Banks averagely disclose 64.7 percentage of this information as well as the maximum and minimum disclosure level are 91.6 percentage and 25 percentage respectively There are 16 numbers of Financial Information on $\mathrm{HR}$ are considered in this study to be disclosed in the annual reports but averagely 64.9 percentage of information while Maximally 93.7 percentage and minimally 43.7 percentage are disclosed by banks.

In total 12 HR Relationship \& cultural information are taken to account in this study. Mean disclosure of this information is 59.3 percentage and also some of the bank disclose 100percentage of information under this category while minimally disclose 83.3 percentage. Out of eight items of information in HR Development, on an average 65.7 percentage of information are disclosed by banks. Here it clearly shows that some company disclose all of 8 information in their annual reports while some of the bank failed to disclose even one of the HR Development Information. Similarly, three items are also considered relating to $\mathrm{HR}$ Importance to Organization. The data revealed that banks disclosed 70.7 percentage on an average where minimum is one- third of this information and maximum disclosure is all three information as 100 percentage. The content analysis of HR disclosure of the study consist maximum 4 items relating to Other Factors of HR. On an average banks disclosed 35.7 percentage of this information where also disclose three-four as maximum and some banks failed to disclose even a percentage of this information. Finally, Health \& Safety information relating to HR consists of only 3 indicators out of which banks on an average disclosed just above than 50 percentage $(51.5 \%)$ where minimum disclosure level is zero percent and maximum is 100 percent. Therefore it clearly mentions that some of the bank should consider on their disclosure level on the Health \& safety information of HR.

Table 5. Descriptive statistics for Category-wise HR disclosure of Listed Commercial Banks

\begin{tabular}{l|ccrrr}
\hline Category & Obs & Mean & Std.Dev & Min & Max \\
\hline HR Policies (\%) & 65 & 0.844 & 0.176 & 0.333 & 1.000 \\
Basic HR Information (\%) & 65 & 0.647 & 0.182 & 0.250 & 0.916 \\
Financial Information on HR (\%) & 65 & 0.649 & 0.137 & 0.437 & 0.937 \\
HR Relationship \& Culture (\%) & 65 & 0.593 & 0.242 & 0.833 & 1.000 \\
HR Development (\%) & 65 & 0.657 & 0.256 & 0.000 & 1.000 \\
HR Importance to Organization (\%) & 65 & 0.707 & 0.172 & 0.333 & 1.000 \\
HR Other Factors (\%) & 65 & 0.357 & 0.171 & 0.000 & 0.750 \\
Health \& Safety (\%) & 65 & 0.515 & 0.229 & 0.000 & 1.000 \\
\hline
\end{tabular}

Source: Results from the panel data analysis

Table 6 indicates the descriptive statics of words, graphs, charts and pictures which are used by banks in their annual reports for HR disclosure. Banks used averagely 2306.8 words to disclose HR disclosure while the maximum and minimum words are 4235 and 958 respectively used by banks. There are 5 graphs are averagely used by banks and also 22 is the maximum graphs while some of the banks did not use any graphs in their annual reports to disclose HR information. Banks used averagely 5 charts for disclose about HR and some of the 
banks used no any charts for HR disclosure as well as some banks used maximally 22 charts in their annual reports for HR disclosure. Lastly, banks averagely used 11 pictures to Table 6. Descriptive statics of Words, Graphs, Charts and Pictures are used for HR disclosure

\begin{tabular}{l|ccccc}
\hline Ways of HR disclosure & Obs & Mean & Std.Dev & Min & Max \\
\hline Words (Nos) & 65 & 2306.8 & 834.4 & 958 & 4235 \\
Graphs (Nos) & 65 & 5.446 & 4.572 & 0 & 22 \\
Charts (Nos) & 65 & 5.661 & 4.542 & 0 & 21 \\
Pictures (Nos) & 65 & 3.89 & 2.834 & 0 & 11
\end{tabular}

Source: Results from the panel data analysis

Correlation analysis

Table 7 indicates that ' $r$ ' value between the TA and HRDI is 0.6868. It determines that there is a positive relationship between company firm size and HR disclosure and also which is significant at $p<0.01$ level. Strength of the association also good as above the moderate $(r=0.6868)$. Therefore it implies that when the size of a firm increases, the extent of HR disclosure increases. The results of this study is consistent with prior empirical studies of Hafij, Uddin and Khanam (2014); Huui and Siddiq (2012); Mamun (2009) \& Maheswari (1993).Results also identify that there is a significant positive relationship between AGE and HRDI at 0.01 level $(r=0.5800)$. This shows that when age of a firm increases, level of HR disclosures in the annual reports will increase. The ' $r$ ' value shows that strength of association is above the moderate. This result is consistent with some previous literatures such as Huui and Siddiq (2012) \& Singhvi and Desai (1971).

The correlation analysis also determines that the EPS has a positive relationship with HRDI $(\mathrm{r}=0.3723)$ and also which is significant at $P<0.05$ level. It shows that increases on profitability create the ways to disclose HR information thus maximum number of pictures are used by bank is 11 and minimum is 0 . increase the extent of HR disclosure in the annual reports. And also ' $r$ ' value indicates the association that is not high but less than moderate. Even though the relationship implies that the profitability increases, the level of HR disclosure also will increase. The result of Hafij et al.,2014; Huui and Siddiq (2012) \& Haniffa and Cooke (2002) also consistent with this study. There is a positive correlation between the leverage and HRDI but which is not significant at any level and the $r$ value shows association is not moderate but it just correlate among them. Therefore according to the result, percentage of the leverage increases, level of HR disclosure also will increase. This result is consistent with prior studies of Haniffa and Cooke (2002), Oliveira et al. (2006) and Prencipe (2004). 
Table 7. Pairwise Correlation of LTA, AGE, DAR and HRDI

\begin{tabular}{cccccc}
\hline & TA & AGE & EPS & DAR & HRDI \\
\hline TA & 1.0000 & & & & \\
AGE & 0.5494 & 1.0000 & & & \\
EPS & 0.6861 & 0.2658 & 1.0000 & & \\
DAR & 0.3129 & -0.2644 & 0.2634 & 1.0000 & \\
HRDI & $0.6868 * * *$ & $0.5800^{* * *}$ & $0.3723^{* *}$ & 0.0214 & 1.0000 \\
\hline
\end{tabular}

Source: Results from the panel data analysis

$* p<0.1$, **p $<0.05, * * * p<0.01$

Multicollinearity

Multicollinearity implies the existence of a linear relationship between two or more explanatory variables. If there is a perfect linear relationship among the explanatory variables, the estimates for a regression model cannot be uniquely computed. There is no formal criterion for determining the bottom line of the tolerance value or variance inflation factor (VIF). Some argue that a tolerance value less than 1 or VIF greater than 10 roughly indicates significant multicollinearity (Jee, 2002). Table 8 shows the finding of this analysis explains that there is no multicollinearity, as the highest value of the VIF is less than 10 and the tolerance factor is below 1 .

Table 8. Variance Inflation Factor (VIF) and Tolerance of Independent Variables

\begin{tabular}{ccc}
\hline Variable & VIF & 1/VIF \\
\hline LTA & 3.37 & 0.2969 \\
AGE & 2.12 & 0.4724 \\
EPS & 1.97 & 0.5081 \\
DAR & 1.59 & 0.6286 \\
\hline
\end{tabular}

Source: Results from the panel data analysis

Regression analysis

Table 9 presents finding of regression analysis with information on the impact of an independent on the dependent variable. In the sample firm, $\mathrm{R}^{2}$ value of firm attributes on HRDI indicates that 54.69 percentage of observed variability on HRDI can be explained by the firm attributes. The $F$-statistics and significance levels show that model generates statistically significant outcomes. It illustrates the adjusted $r^{2}$ value of 0.5167 with the $p$-value of 0.000 and this model indicates that there is a significant variation of firm attributes on HRDI at $p<0.05$. It means that 51.67 percentage of impact is created by LTA, AGE, EPS and DAR on HRDI. Whereas remaining 48 percentage (approximately) of impact is made by other variables which are not depicted in the model.

Table 9. Regression Model Summary between HRDI and LTA, AGE, EPS, DAR

\begin{tabular}{l|l}
\hline Number of obs & 65 \\
$\mathrm{~F}(4,65)$ & 18.11 \\
Prob $>\mathrm{f}$ & 0.0000 \\
R-squared & 0.5469 \\
\hline
\end{tabular}




\begin{tabular}{l|l}
\hline Adj R-squared & $\mathbf{0 . 5 1 6 7}$ \\
Root MSE & 0.0970 \\
\hline
\end{tabular}

Source: Results from the panel data analysis

Table 10 displays the results of the coefficient estimation for each firm attributes. The impact of LTA ( $t=4.43$ and $p=0.000$ ) and HRDI is significant at $p<0.01$ level therefore it implies that changes in the firm size significantly impact the level of HR disclosure. As well as Table 10. Regression Model between HRDI and LTA, AGE, EPS, DAR

\begin{tabular}{c|cccccc}
\hline HRDI & Coef. & Std. Err & $\mathrm{T}$ & $\mathrm{P}>(\mathrm{t})$ & $95 \%$ con. & Interval \\
\hline TA & 0.0834 & 0.0188 & 4.43 & 0.000 & 0.0457 & 0.1210 \\
AGE & 0.0018 & 0.0011 & 1.58 & 0.120 & -0.0005 & 0.0041 \\
EPS & -0.0014 & 0.0013 & -1.11 & 0.272 & -0.0040 & 0.0011 \\
DR & -0.2292 & 0.2267 & -1.01 & 0.317 & -0.6831 & 0.2247 \\
Cons & -1.3518 & 0.4038 & -3.35 & 0.001 & -2.1594 & -0.5441 \\
\hline
\end{tabular}

Source: Results from the panel data analysis Hypotheses testing

Multi correlation and regression analysis are used to test the developed hypotheses of the study.

$\mathrm{H}_{1}$ : There is a significant impact of firm attributes on HR disclosures

According to regression model summary (table-10), Adj R-squared value is 0.5167 and its corresponding $\mathrm{P}$ value is 0.000 . So this says that there is a significant impact (because $\mathrm{p}<0.05$ ) of firm attributes on HR disclosure of listed commercial banks in Sri Lanka.

$H_{1 a}$ : There is a significant impact of firm size on HR disclosure

$\mathrm{H}_{1 \mathrm{a}}$ is supported. Table- 11 indicates the $p$ value for firm size is $0.000(t=4.43 ; p<0.001)$. This clearly shows that there is a significant impact of firm size on HR disclosure at $1 \%$ level.

Table 11. Summary of the Hypotheses Tested

\begin{tabular}{ccccc}
$\begin{array}{c}\text { Hypothesis } \\
\text { number }\end{array}$ & $\begin{array}{c}\text { Impact of firm attributes on HR } \\
\text { disclosure }\end{array}$ & Expected impact & Results & Outcome \\
\hline $\mathrm{H}_{1 \mathrm{a}}$ & Firm size on HR disclosure & Significant $+/-$ & $\mathrm{P}<0.05$ & Accepted
\end{tabular}

there are an insignificant outcomes between AGE and HRDI $(t=1.58$ and $p=0.120)$, EPS and HRDI $(t=-1.11$ and $p=0.272)$, and also between DAR and HRDI $(t=1.01$ and $p=0.317)$.

$H_{l b}$ : There is a significant impact of age on $H R$ disclosure

$\mathrm{H}_{1 \mathrm{~b}}$ is not supported. Table - 11 indicates the $p$ value for age is $0.120(t=1.58 ; P>0.05)$. This clearly indicates that there is no significant impact of firm age on HR disclosure.

$H_{l c}$ : There is a significant impact of profitability on HR disclosure

$\mathrm{H}_{1 \mathrm{c}}$ is also not supported. Table-11 indicates the $p$ value for profitability is $0.272(t=-1.11$; $p>0.05)$. This clearly shows that there is no significant impact of EPS on HR disclosure.

$H_{1 \mathrm{~d}}$ : There is a significant impact of leverage on HR disclosure

$\mathrm{H}_{1 \mathrm{~d}}$ is also not supported. Table-11 indicates the $p$ value for leverage is $0.317(t=-1.01$; $p>0.05)$. This clearly shows that there is no significant impact of leverage on HR disclosure. 


$\begin{array}{ccccc}\mathrm{H}_{1 \mathrm{~b}} & \text { Age on HR disclosure } & \text { Significant }+/- & \mathrm{P}>0.05 & \text { Rejected } \\ \mathrm{H}_{1 \mathrm{c}} & \text { Profitability on HR disclosure } & \text { Significant }+/- & \mathrm{P}>0.05 & \text { Rejected } \\ \mathrm{H}_{1 \mathrm{~d}} & \text { Leverage on HR disclosure } & \text { Significant }+/- & \mathrm{P}>0.05 & \text { Rejected }\end{array}$

$\mathrm{H}_{2}$ : There is a significant relationship between $1 \%$ significant level $(\mathrm{p}<0.01)$. Further, this says firm attributes and HR disclosures

$H_{2 a}$ : There is a significant relationship between firm size and HR disclosure

$\mathrm{H}_{2 \mathrm{a}}$ is supported. Table- 08 shows that there is a positive significant relationship between TA and HRDI ( $\mathrm{r}=0.6868)$. This is significant at $1 \%$ significant level $(p<0.01)$. Further, this says the moderate relationship between these two variables.

$H_{2 b}$ : There is a significant relationship between age and HR disclosure

$\mathrm{H}_{2 \mathrm{~b}}$ is supported. Table- 08 shows that there is a positive significant relationship between firm age and HRDI ( $\mathrm{r}=0.5800)$. This is significant at the moderate relationship between these two variables.

$H_{2 C}$ : There is a significant relationship between EPS and HR disclosure

$\mathrm{H}_{2 \mathrm{C}}$ is supported. Table-08 shows that there is a positive significant relationship between EPS and HRDI ( $\mathrm{r}=0.3723)$. This is significant at $5 \%$ significant level $(\mathrm{p}<0.05)$. Further, this says the weak relationship between these two variables.

$H_{2 d}$ : There is a significant relationship between leverage and HR disclosure

$\mathrm{H}_{2 \mathrm{~d}}$ is supported. Table-08 shows that there is a positive relationship between leverage and HRDI ( $r=0.0214)$. This is not significant at any significant level.

Table 12. Summary of the Hypotheses Tested

\begin{tabular}{ccccc}
$\begin{array}{c}\text { Hypothesis } \\
\text { number }\end{array}$ & $\begin{array}{c}\text { Relationship between firm } \\
\text { attributes and HR disclosure }\end{array}$ & Expected impact & Results & Outcome \\
\hline $\mathrm{H}_{2 \mathrm{a}}$ & Firm size and HR disclosure & Significant $+/-$ & $0.6868 * * *$ & Accepted \\
$\mathrm{H}_{2 \mathrm{~b}}$ & Age and HR disclosure & Significant $+/-$ & $0.5800^{* * *}$ & Accepted \\
$\mathrm{H}_{2 \mathrm{c}}$ & Profitability and HR disclosure & Significant $+/-$ & $0.3723^{*}$ & Accepted \\
$\mathrm{H}_{2 \mathrm{~d}}$ & Leverage and HR disclosure & Significant $+/-$ & 0.0214 & Rejected \\
\hline
\end{tabular}

\section{Concluding remarks}

The findings of the study indicates that only size variable (the size of the firm), which has a significant influence on the HR disclosure. Thus, it can be concluded that firm size is a major predictor that may affect the variety of HR disclosure practices on firms listed in the CSE, Sri Lanka. On the other hand, variables of firm age, EPS and leverage bring no significant influence on the ICD. Further, content analysis indicates that there is more tendency of using words as a way of making HR disclosure of listed commercial banks in Sri Lanka. Even though, Sri Lankan banks pay more attention to disclose HR policy related issues more and more in the annual reports than disclosing other items.

Limitations of the study and future research directions

This study only considered 13 commercial banks listed in CSE, Sri Lanka for five year period from 2013 to 2017. Therefore, any future study may conduct as longitudinal study by taking more number of financial years. In addition, this study can be replicated by considering sample of firms from another 
country as comparative analysis/cross sectional studies, which would enhance the understanding of the factors explaining the level of voluntary HR disclosure. Another recommendation for future study, that it would be analysing another media of communication used by the companies, like the information disclosure in the internet via websites than only rely on annual reports.

\section{References}

Abeyasekara, I., \& Guthrie, J. (2004). Human capital reporting in a developed nation. The British Accounting Review, 36, 251-268.

Abeysekera, I., \& Guthrie, J. (2005). An empirical investigation of annual reporting trends of intellectual capital in Sri Lanka. Critical Perspectives on accounting, 16(3), 151-163.

Akinpelu, Y., Ogunbi, O., Olaniran, Y., \& Ogunseye, T. (2013). Corporate Social Responsibility Activities Disclosure by Commercial Banks in Nigeria. European Journal of Business and Management.

Alam, I., \& Deb.S.K. (2010). Human resource accounting disclosure (HRAD) in Bangladesh: multifactor regression analysis-a decisive tool of quality assessment. The cost and Management, 38(3), 9-13.

América Álvarez Domínguez, M. (2012). Company characteristics and human resource disclosure in Spain. Social responsibility journal, 8(1), 4-20.

América Álvarez Domínguez, M. (2012). Company characteristics and human resource disclosure in Spain. social responsiibily journal, 4-20.

An, Y., Davey, H., \& Eggleton, I. (2011). Towards a comprehensive theoretical framework for voluntary IC disclosure. Journal of Inteelctual Capital, 571-585.

Bassi, L. J., Lev, B., Low, J., McMurrer, D. P., \& Siesfeld, G. A. (2000). Measuring corporate investment in human capital: the new relationship.

Beattie, V. (2014). Accounting narratives and the narrative turn in accounting research Issues, theory, methodology, methods and a research framework. The British Accounting Review, 111134.

Beattie, V., \& Thomson, S. J. (2007, June). Lifting the lid on the use of content analysis to investigate intellectual capital disclosures. In Accounting Forum (Vol. 31, No. 2, pp. 129-163). Elsevier.

Belkaoui, A., \& Karpik, P. (1989). Determinants of the Corporate Decision to Disclose Social Information. Accounting, Auditing \&Accountability Journal, 36-51.

Berger, A., \& Patti, B. d. (2006). Capital structure and firm performance A new approach to testing agency theory and an application to the banking industry. Journal of Banking and Finance, 1065-1102.

Bharathi Kamath, G. (2008). Intellectual capital and corporate performance in Indian pharmaceutical industry. Journal of Intellectual Capital, 9(4), 684-704.

Binh, T. ,. (2012). Voluntary Disclosure Information in the Annual Reports of Non Financial Listed Companies: The Case of Vietnam. Journal of Applied Economics and Business Research, 69-90.

Binh, T. (2012). Voluntary Disclosure Information in the Annual Reports of Non Financial Listed Companies: The Case of Vietnam. Journal of Applied Economics and Business Research, 69-90.

Boesso, G., \& Kumar, K. (2007). Drivers of corporate voluntary disclosure: A framework and empirical evidence from Italy and the United States. Accounting, Auditing \& Accountability Journal,20(2), 269 296.

Boolaky, P. (2011). Global Reporting Initiatives (G3), Standard Disclosures 
for Human Resource Practices: Compliance and Determinants in The Financial Services Sector. Europe, Asia and Others Academy of Taiwan Business Management Review, 1-15.

Bozzolan, S., Favotto, F., \& Ricceri, F. (2003). Italian annual intellectual capital disclosure: an empirical analysis. Journal of Intellectual capital, 4(4), 543-558.

Brammer, S., \& Pavelin, S. (2006). Voluntary environmental disclosures by large UK companies. journal of business finance \& accounting, 1164-1188.

Broberg, P., Tagesson, T., \& Collin, S.-O. (2010). What explains variation in voluntary disclosure? A study of the annual reports of corporations listed on the Stockholm Stock Exchange. Journal of Management \& Governance, 351-377.

Brown, A., Tower, G., \& Taplin, R. (2005). Human resources disclosures in the annual reports of Pacific Island countries' entities. Asia Pacific Journal of Human Resources, 43(2), 252-272.

Bukh, P. (2003). Commentary: The relevance of intellectual capital disclosure: a paradox? Accounting, Auditing \& Accountability Journal, 16(1), 49-56.

CIMA. (2001, September). Managing the intellectul capital within today's knowledge-based Organisations. Technical Brifefing.

Cuganesan, S. (2006). eporting organizational performance in managing human resources: intellectual capital or stakeholder perspectives. Journal of human costing and accoounting, 164188.

Cuganesan, S. (2007). Reporting organisational performance in managing human resources Intellectual capital or stakeholder perspectives? . Journal of Human Costing \& Accounting, 164188.

Cuganesan, S., Carlin, T., \& Finch, N. (2009). The Practice of Human Capital Reporting Among Australian
Financial Institutions. Journal of Finance and Accountancy, 1-9.

Debreceny, R., \& Rahman, A. (2005). Firm specific determinants of continuous corporate disclosures. The international Journal of Accounting, 40(3), 249-278.

Deegan. (2006). Legitimacy theory. london: Spiramus Press.

Deegan, C., \& Unerman, J. (2011). Financial Accounting Theory. Berkshire: McGraw-Hill Education.

Firer, S., \& Mitchell Williams, S. (2003). Intellectual capital and traditional measures of corporate performance. Journal of intellectual capital, 4(3), 348-360.

Flamholtz, E. (2001). Human resource accounting: a historical perspective and future implications. Journal of Management decision.

Flamholtz, E. G., Bullen, M. L., \& Hua, W. (2002). Human resource accounting: a historical perspective and future implications, Management Decision.

Fontana, F., \& Macagnan, C. (2013). Factors explaining the level of voluntary human capital disclosure in the Brazilian capital market, Intangible Capital. Intangible Capital, 305-321.

Francis, J., \& Schipper, K. (1999). Have financial statements lost their relevance?.Journal of accounting Research, 37(2), 319-352

Freeman, R. (2010). Strategic management. Newyork: Cambridge University Press.

Giner, B. (1997). The influence of company characteristics and accounting regulation on information disclosed by Spanish firms. the european accounting review, 45-68.

Goh, P. C. (2005). Intellectual capital performance of commercial banks in Malaysia. Journal of Intellectual capital, 385-396.

Graham, J. R., Harvey, C. R., \& Puri, M. (2015). Capital allocation and delegation of decision-making authority within firms. Journal of 
Financial Economics, 115(3), 449470.

Guo, R., Lev, B., \& Zhou, N. (2005). The valuation of biotech IPOs. Journal of Accounting Auditing \& Finance, , 429459.

Guthrie, J., \& Petty, R. (2000). Intelectual capital literature review. Journal of Intelectual Capital, 1(2), 155-176.

Guthrie, J., \& Petty, R. (2000). Intellectual capital literature review. Journal of Intellectual Capital, 1(2), 155-176.

Guthrie, J., Petty, R., \& Ricceri, F. (2006). The voluntary reporting of intellectual capital: Comparing evidence from Hong Kong and Australia. Journal of intellectual capital, 7(2), 254-271.

Hafij, U., Uddin, H., \& Khanam, R. (2014). Relationship between Human Resource Disclosure and Company Attributes: An Empirical Study on Textile Companies in Bangladesh. International Journal of Accounting and Financial Reporting, 571-586.

Haniffa, R. M., \& Cooke, T. M. (2002). Culture, Corporate Governance and Disclosure in Malaysian Corporations. Abacus, 317-349.

Handley, S. M., Juleff, L., \& Paton, C. (2007). Corporate governance in the financial services sector. Corporate Governance, 623-634.

Hossain, M., \& Hammami, H. (2009). Voluntary disclosure in the annual reports of an emerging country: The case of Qatar. Advances in Accounting, 255-265.

Hossain, D. M., Khan, A., \& Yasmin, I. (2004). The nature of voluntary disclosures on human resource in the annual reports of Bangladeshi companies.

Huui, L. M., \& Siddiq, M. (2012). Human Resource Disclosure: The Current Practice and its association with Corporate Characteristics in Malaysia. Interdisciplinary journal of contemporary research in business, 68-93.

Jee, S. (2002). Multicollinearity in Regression Model. Multicollinearity, 6-8.
Jenses, M., \& Meckling, W. (1976). Theory of the firm: managerial behaviour, agency costs and ownership structure. Journal of Financial economics, 305360.

Jindal, S., \& Kumar, M. (2012). The determinants of $\mathrm{HC}$ disclosures of Indian firms. Journal of intellectual capital, 221-247.

Khan, M. H., \& Khan, M. R. (2010). Human capital disclosure practices of top Bangladeshi companies. Journal of Human Resource Costing \& Accounting, 329-349.

Khan, M., \& Khan, M. (2010). Human capital disclosure practices of top Bangladeshi companies. Journal of human resource costing \& accounting, 329-349.

Lev, B. (2004). Sharpening the intangibles edge. Harward business review, 82(6), pp. 109-116.

Lev, B., \& Zarowin, P. (1999). The boundaries of financial reporting and how to extend them. Journal of Accounting research, 37(2), 353-385.

Li, J., Mangena, M., \& Pike, R. (2012). The effect of audit committee characteristics on intellectual capital disclosure. The British Accounting Review, 44(2), 98-110.

Li, J., Pike, R., \& Haniffa, R. (2008). Intellectual capital disclosure and corporate governance structure in UK firms. Accounting and Business Research, 137-159.

Lobo, G., \& Zhou, J. (2001). Disclosure quality and earnings management, Paper presented at the 2001 Asia-Pacific. Journal of Accounting and Economics Symposium in Hong Kong.

Macagnan, C. (2009). Evidenciação voluntária: fatores explicativos da extensão da. Journal of Contabilidade \& Finanças, 20(50), 46-61.

Maheshwari, G.C. (1993), “Corporate characterstics and social responsibility reporting", Asian Review of Accounting, Vol. 1 No. 1, pp. 31-42. 
Mamun. (2009). Human Resource Accounting (HRA) disclosure of Bangladeshi companies and its association with corporate characteristics. BRAC University Journal.

Micah, L., Ofurum, C., \& Ihendinihu, J. (2012). Firms Financial Performance and Human Resource Accounting Disclosure in Nigeria. International Journal of Business and Management.

Mondal, A., \& Ghosh, S. K. (2012). Intellectual capital and financial performance of Indian banks. Journal of Intellectual Capital, 515-530.

Morris, R. (1987). Signalling, agency theory and accounting policy choice. Accounting Business Research, 47-56.

Neu, D., Warsame, H., \& Pedwell, K. (1998). Managing public impressions: envrironmental disclosures in annual reports. Accounting, Organizations and Society, 265-282.

Olagunju, A., Olurin, O. T., \& Okuyemi, M. (2012). Corporate social responsibility reporting and financial performance of money deposit banks in Nigeria. Prime Journal of Business Administration and Management, 758769.

Oliveira, L., Rodrigues, L. L., \& Craig, R. (2006). Firm-specific determinants of intangibles reporting: Evidence from the Portuguese stock market. Journal of HRCA: Human Resource Costing \& Accounting, 11-33.

Rimmel, G., Nielsen, C., \& Yosano, T. (2009). Intellectual capital disclosures in Japanese IPO prospectuses. Journal of Human Resource Costing \& Accounting, 316-337.

Roberts, R. (1992). Determinants of corporate social responsibility disclosure. Accounting, Organization and Society, 595-612.

Samudhram, A., Sivalingam, G., \& Shanmugam, B. (2010). Nondisclosure of human capital-based information: theoretical perspectives. Journal of Human Resource Costing \& Accounting, 106-128.
Schultz, T. W. (1961). Investment in Human Capital. American Economic Review, $1-17$.

Singhvi, S. S., \& Desai, H. B. (1971). An empirical analysis of the quality of corporate financial disclosure. The Accounting Review, 46(1), 129-138.

Singh, I., \& Van der Zahn, J.-L. W. (2010). Determinants of intellectual capital disclosure in prospectuses of initial public offerings. Accounting and Business Research, 409-431.

Spence, M. (1977). Nonlinear prices and welfare. Journal of public economics, 8(1), 1-18.

Subramaniam, N. (2006). Agency theory and accounting research: an overview of some conceptual and empirical issues. Mrthodologies issues in accounting research: theories and methods, 5557.

Subramaniam, N. (2006). Agency theory and accounting research: an overview of some conceptual and empirical issues.

Sveiby, K. (1997). The new organisational wealth:managing and measuring knowledge-based assets. SanFransico: CA:Berrett-Koehler Publishers.

Tayles, M., Pike, R., \& Sofian, S. (2007). Intellectual captal, management accounting practices and corporate performance: percepations of maangers. Accounting, Auditing \& accounatbility Journal, 20(4), 522.

Ullah, M. H., Uddin, M. H., \& Khanam, R. (2015). Relationship between human resource disclosure and company attributes: An empirical study on textile companies in Bangladesh. International Journal of Accounting and Financial Reporting, 4(2), 571-586.

Upadhyay, D. K., \& Dhungel, A. (2013). Corporate Social Responsibility Reporting Practices in the Banking Sector of Nepal. Banking Journal, 6178 .

Upadhyay, D., \& Dhungel, A. (2012). Corporate social responsibility 
reporting practices in the banking sector of Napal. Banking Journal, 6178.

Wagenhofer, A. (1990). Voluntary Disclosure witha strategic opponent. Journal of Accounting and Economics, 12, 341363.

Watson, A., Shrives, P., \& Marston, C. (2002). Voluntary Disclosure of Accounting Ratios in the UK. British Accounting Review, 289-313.

Watts, R., \& Zimmerman, J. L. (1983). Agency problems, auditing and theory of the firm: some evidence. Journal of Law \& Economics, 613-633.

White, G., Lee, A., \& Tower, G. (2007). Drivers of voluntary intellectual capital disclosure in listed biotechnology companies . Journal of Intellectual Capital, 517-537.

Whiting, R. H., \& Miller, J. C. (2008). Voluntary disclosure of intellectual capital in New Zealand annual reports and the "hidden value". Journal of Human resource costing and accounting, 26-50.

Whiting, R. H., \& Woodcock, J. (2011). Firm characteristics and intellectual capital disclosure by Australian companies. Journal of Human Resource Costing \& Accounting, 102-126.

Wickramasinghe, V., \& Fonseka, N. (2012). Human resource measurement and reporting in manufacturing and service sectors in Sri Lanka. Journal of Human Resource Costing \& Accounting, 232-255.

Williams, S. (2001). Is intellectual capital performance and disclosure practices related? Journal of Intellectual Capital, 2(3), 192-203. 